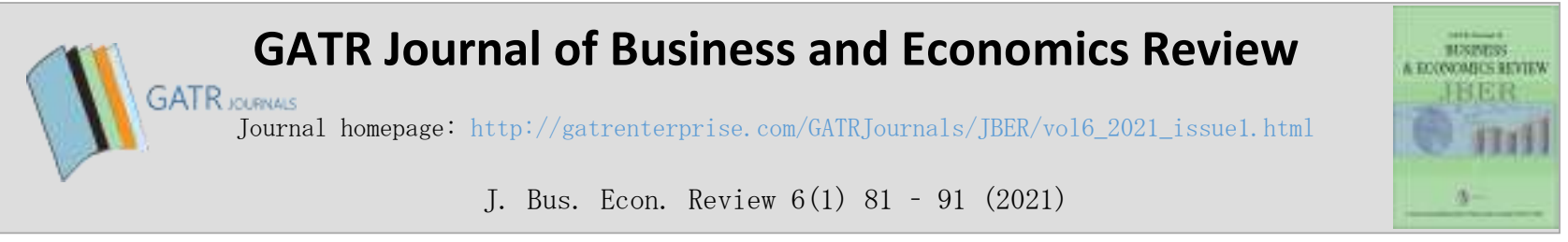

\title{
Impacts of COVID-19 on Airline Business: An Overview
}

\author{
Teeris Thepchalerm ${ }^{1 *}$, Phutawan $\mathbf{H o}^{2}$ \\ ${ }^{1,2}$ Business Excellence and Logistics Research Centre, School of Management, Mae Fah Luang University, 333 Moo.1 Thasud Sub- \\ district, Muang Chiangrai District, 57100, Chiang Rai, Thailand
}

\begin{abstract}
Objective - This article aims to preliminarily examine and summarize the impact of COVID-19 on airline business and to briefly investigate how the airlines respond.

Methodology/Technique - The researchers synthesize data and information collected from industry organizations' reports and related academic literature. A traditional narrative literature review was implemented to examine and summarize the impacts of COVID-19 on the airline business.

Findings - The results show that COVID-19 has operational, market, and financial impacts on airline business. In response to the COVID-19 situation, the airlines have updated their operational procedures and searched for alternative revenue streams. The authors also provide suggestions for future research.

Novelty - COVID-19 is an emerging infectious disease. Very few scholars have conducted studies on the impacts of COVID-19 on airline business. This article contributes to the academic literature by categorizing the impacts of COVID-19 on airline business. Future studies can further investigate the impacts of COVID-19 on airline business using this article as a starting point.
\end{abstract}

Type of Paper: Review.

JEL Classification: M10, R41.

Keywords: Airlines; COVID-19; Air Transport; Aviation; Infectious Disease

Reference to this paper should be made as follows: Thepchalerm, T; Ho, P. 2021. Impacts of COVID-19 on Airline Business: An Overview, J. Bus. Econ. Review, 6(1), 81-91. https://doi.org/10.35609/jber.2021.6.1(1)

\section{Introduction}

Coronavirus Disease 2019, or COVID-19, has spread globally and has been classified as a global pandemic by the World Health Organization (WHO, 2020a). The virus has enormous social and economic impacts. The United Nations Industrial Development Organization (2020) expects that the 2020 global GDP will range between $-8 \%$ to $1 \%$ depending on the situation over the last 6 months of 2020 . Various businesses - tourism, hospitality, restaurants, and transportation - have been affected by this pandemic. The airline business is one of the most vulnerable businesses since it is highly sensitive to change in the market environment and socio-economic factors (Wittmer et. al., 2011).

\footnotetext{
* Paper Info: Revised: April 25, 2021

Accepted: June 30, 2021

* Corresponding author: Teeris Thepchalerm

E-mail: teeris.the@mfu.ac.th

Affiliation: School of Management, Mae Fah Luang University, Thailand
}

Airline business has always been dramatically affected during crisis circumstances (Figure 1), for example, the Asian economic crisis in 1998, the USA terrorist attack in 2001, and the severe acute respiratory 
syndrome (SARS) virus spreading in 2003. Infectious diseases such as SARS and COVID-19 can cause enormous impacts on the airline business. For instance, the airlines lost 7 billion USD in revenue solely because of SARS in 2003 (IATA, 2006). It is possible to expect a much more noticeable impact caused by the COVID-19 pandemic than the SARS impact in 2003 because of the much higher infection rate and the duration of COVID-19 compared to SARS. Moreover, the market environment has changed, especially in terms of size. The number of airline passengers per year has increased from 2 billion in 2003 to 4.5 billion in 2018 (IATA, 2019). Therefore, the International Air Transport Association (IATA, 2020a) forecasts that the airline industry will need at least 3 to 4 years to recover. During this challenging time, any information regarding COVID-19 and its relationship to the airline business is urgently required. This paper aims to provide an overview of the impact of the COVID-19 pandemic on airline business from different perspectives and examine how airlines have responded to this crisis.

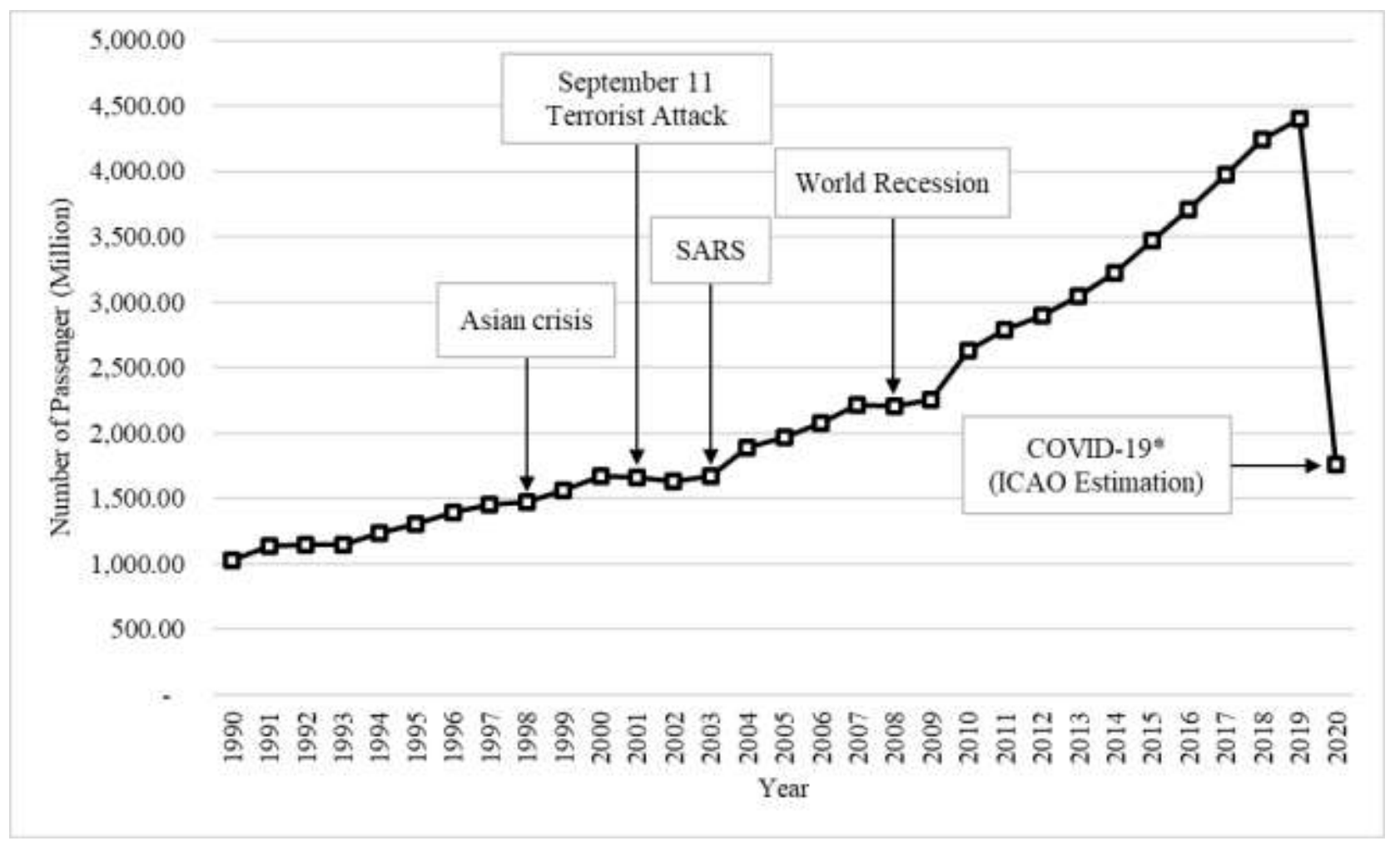

Figure 1. World Aviation and the World Economy

Source: World Bank (2021) and ICAO (2021)

\section{Literature Review}

\subsection{Airline Business: Market, Operations and Finance}

Wittmer et. al. (2011) suggests that the aviation system consists of the demand-side and supply-side, and the airline business is a significant player in the aviation supply-side. The airline's role is to provide air transportation to passengers and freight; thus, the airline's products are seats for passenger, space for freight, and the route network (Doganis, 2019). The airline market has been consistently growing over the last 10 years. According to ICAO (2019), passengers and freight volume in 2019 reached more than 4 billion passengers and 57 million tons of freight compared to only 2.7 billion passengers and 48 million tons of freight in 2010. Despite this favourable increase in the number of passenger and freight, the airline market is 
highly sensitive and subject to unexpected situations. For instance, the September 11th terrorist attack, SARS, and Avian Influenza pandemic have severely impacted the demand for air transportation. Further, as a result of market expansion, competition in the airline industry is considerably high. The airlines' competition mainly focuses on price and service quality depending on the business model of an airline, e.g., full service or low-cost airline (Budd \& Ison, 2017; Doganis, 2019).

Airline operations are a very complex process that involves many different activities. Airline operations can be broadly categorized into ground operations and flight operations (Budd \& Ison, 2017). The ground operations consist of a number of activities, for example, passenger check-in and boarding, baggage handling, catering, and aircraft ground handling. Flight operation is mainly concerned with aircraft operation and air navigation (Wittmer et. al., 2011; Budd \& Ison, 2017). In order to maintain safety standards and service quality, both ground and flight operations must function properly. Evler et. al. (2021) suggests that the airline's time slot and timetable are very important factors determining daily operation processes. In other words, both ground and flight operations must complete their tasks according to each flight's arrival and departure time, so each flight that arrives and departs is not delayed (Belobaba et. al., 2016).

Moreover, most airlines have adopted hub and spoke networks, so there shall be one or more hub airports that connect many other airports. This model allows the airlines to offer more route choices to passengers (Doganis, 2019). Despite the benefits of the hub and spoke model, it increases the complexity of airline operations because there will be many arrival and departure flights. The airlines also need to manage transfer passengers at the hub airports (Belobaba et. al, 2016; Doganis, 2019). In addition, airline operations are highly regulated. There are many rules, regulations and guidelines issued by aviation authorities such as ICAO and IATA (Wittmer et. al., 2011). These authorities usually update regulations and guideline according to the temporary and current situations. These changes in regulations and guidelines can greatly affect the airlines (Macilree \& Duval, 2021).

Airline financial management consists of revenue and cost management. In general, an airline earns revenue by selling tickets and space, while an airline's costs vary, including operational, managerial, and investment costs (Belobaba et. al., 2016). Therefore, the airlines need to fill up the aircraft with passengers and cargo and charge the fares sufficient to cover operational costs and to generate profit. Morrison et. al. (2010) found that fuel costs account for almost 35\% of airlines' operational cost. Thus, the longer the flight is, the higher the cost will be. Another essential cost of an airline is the interest payment. Airline business requires a massive amount of investment, especially for aircraft procurement. The airlines generally get funding from loans and leasing. As a result, most airlines have a huge amount of debt which causes considerable interest burdens on the airline (Budd \& Ison, 2017; Aydin et. al., 2020). In addition, Aydin et. al. (2020) found that airlines' financial performance is not desirable.

\subsection{Airline Business and Infectious Diseases}

The COVID-19 pandemic has had an enormous impact on the airline industry, yet it is not the first time that this industry has to deal with the impact of a global virus. The Severe Acute Respiratory Syndrome (SARS) and Avian Influenza virus have previously had a negative effect on the airline industry (Mason, 2005). However, there are very few studies focusing on the impacts of these infectious diseases on the airline business. The majority of academic literature pays attention to the role of airlines and air transportation in disease diffusion since the diseases can spread globally via air transportation when infected passenger travel across countries (Hertzberg et. al., 2018). For example, a study on the SARS epidemic in 2002 and 2003 by Bowen and Laroe (2006) found that air transportation is one factor that accelerates the speed of a virus across countries. Mason (2005) suggested that infectious diseases such as SARS and Avian Influenza can negatively affect airline businesses. For instance, people might stop traveling to the epidemic areas, or some countries' 
governments might prohibit their citizens from traveling to some destinations. Kuo et. al. (2008) found that air transportation demand in SARS-affected countries significantly decreased during the epidemic.

Another study by Pine and McKercher (2004) also found that the SARS epidemic had a significant impact on the Hong Kong tourism industry. For example, Cathay Pacific carried only $30 \%$ of the passenger it carried prior to the SARS epidemic. Infectious diseases also affect airlines' operational procedures. The airlines need to make sure that their crews and passengers are safe. Thus, many preventive measures must be implemented to prevent the diseases from spreading. The airlines have implemented a number of preventive measures from wearing a facial mask and using hand sanitization to medical documents screening (Hester, 2020; Pongpirul et. al., 2020). According to previous literature, infectious diseases can damage the airline business from various perspectives. COVID-19 has spread faster and wider than both SARS and Avian Influenza (Zhu et. al., 2020). The impacts of COVID-19 on airline businesses might be more prominent and last longer than the impact experienced as a result of SARS and Avian Influenza.

\subsection{Airline Businesses and COVID-19}

In this section, the authors provide an introduction to the various impacts of COVID-19 on airline businesses, while an in-detail review on the impacts of COVID-19 on airline businesses is provided in the results section. Like SARS and Avian Influenza, COVID-19 can certainly pose impacts on airline business due to travel regulations and restrictions, economic depression, and people's fear of the disease (Lamb et. al., 2020; Gudmundsson et. al., 2021). The number of flights per day dropped significantly during the first 2 weeks of April 2020, as a result of travel restrictions in many countries (ICAO, 2020). This also caused a commensurate reduction in the demand for air transportation (Gudmundsson et. al., 2021). This leads to financial difficulty for airlines because they cannot earn sufficient revenue during the pandemic. Unfortunately, even before the pandemic, airline financial performance was not satisfactory, reflected in low profits and high debt ratio (Aydin et. al., 2020). COVID-19 also causes difficulty to airline operations. Due to transportation guidance and regulations, airlines have to update and change their operational procedures; for instance, a number of preventive measures has been suggested and implemented (IATA, 2020b; Pongpirul et. al., 2020). According to Gudmundsson et. al. (2021), it will take up to 2.4 years for air transport demand to reach its level from prior to the COVID-19 pandemic. According to the literature review, the authors propose that COVID-19 can affect airline businesses, specifically, airline operations, markets, and financial performance. Further details of the impact of COVID-19 is provided in the results section.

\section{Method}

The authors identified related publications using a standardized search strategy (Table 1). The Scopus and Web of Sciences databases were searched by using the keywords "airline", "COVID-19", "pandemic", and "air transportation". The authors collected additional information from government and industry organizations such as the World Health Organization (WHO), International Air Transportation Association (IATA) and International Civil Aviation Organization (ICAO). The authors also collected information from the airline's official websites. In addition, relevant news from news articles was also collected. The authors then closely examined each publication and conducted a narrative review on each topic. The narrative review was chosen because it is the appropriate method for examining and summarizing a comprehensive topic (Collins \& Fauser, 2005).

Table 1. Sources of information 
Teeris Thepchalerm and Phutawan Ho

\begin{tabular}{lc}
\hline \multicolumn{1}{c}{ Title } & No. \\
\hline Academic Journal & $\mathbf{2 0}$ \\
Transportation Research Part E: Logistics and Transportation Review & 1 \\
Journal of Air Transport Management & 5 \\
The Geographical Journal & 1 \\
Research in Transportation Business \& Management & 1 \\
Air and Space Law & 1 \\
Proceedings of the National Academy of Sciences of & \\
the United States of America & 1 \\
Academy of Strategic Management Journal & 1 \\
International Journal of Infectious Diseases & 1 \\
The Lancet & 1 \\
Transportation Research Interdisciplinary Perspectives & 2 \\
PLOS ONE & 1 \\
Journal of Transport Geography & 1 \\
Journal of Revenue and Pricing Management & 1 \\
Tourism Review & 1 \\
Respiratory Research & 1 \\
News and Industry Organization & $\mathbf{1 6}$ \\
Latime & 1 \\
Forbes & $\mathbf{3 6}$ \\
IATA & 1 \\
ICAO & 1 \\
Matichon & 9 \\
New York Times & 2 \\
Reuter & 1 \\
\hline & 1 \\
\hline & 1 \\
\hline
\end{tabular}

\section{Results - Impacts of COVID-19 on airline business}

COVID-19 affects airline businesses in many ways. These impacts are from the nature of the virus, which is transmittable, so the airlines are required to adjust their operational procedures and comply with various regulations and guidelines to prevent the virus from spreading. The effects also emerge from the negative change in socio-economic factors as a result of the COVID-19 pandemic. The authors have summarized these impacts in 3 ways:

1. Airline operational impacts

2. Airline market impacts

3. Airline financial impacts 


\subsection{Airline operational impacts}

The airlines need to adjust their operational processes and procedures according to the state's government and industry organization's guidelines and regulations, including International Civil Aviation Organization (ICAO) and International Air Transport Association (IATA). The prevention of infection is the top priority, considering that air transport increases the possibility that the virus can spread across countries (Hertzberg et. al., 2018). For instance, an infected person can travel across continents within a day and bring the virus to the destination country. Passengers and crew members are at risk of being infected even if there is only one infected passenger on board. For example, 4 passengers were infected by SARS in one commercial flight (Mangili \& Gendreau, 2005). According to WHO (2020b), the virus that causes COVID-19 disease can be transmitted by droplets generated by coughing or sneezing or direct contact with someone who has respiratory symptoms. IATA (2020b) has provided the guideline for commercial airlines to prevent infection (Table 2). The guidelines consists of 6 main procedures, summarized in Table 2 below.

Table 2. Infection prevention guideline for commercial airlines

\begin{tabular}{ll}
\hline \multicolumn{1}{c}{ Procedure } & \multicolumn{1}{c}{ Brief explanation } \\
\hline Physical distancing & $\begin{array}{l}\text { Passengers and crews should have a certain amount of space during the whole } \\
\text { journey both on the ground and onboard. } \\
\text { Passengers and all staff must wear face masks. }\end{array}$ \\
$\begin{array}{l}\text { Wearing of face covering and } \\
\text { mask }\end{array}$ & The area that exposed to human contact must be disinfected regularly \\
disinfection & $\begin{array}{l}\text { Health screening must be done both pre and post-flight, including self-declaration } \\
\text { and temperature check. } \\
\text { Airlines should collect the updated contact information of passengers and staffs } \\
\text { Contact tracing } \\
\text { Testing }\end{array}$
\end{tabular}

This guideline provides a framework for the airlines to adjust their operational procedures. Some airlines also designed a new uniform that also functions as personal protective equipment (PPE). Some airlines have suspended their food and beverage services to reduce human contact between cabin crew and passengers. The airlines also adjust their ground service procedures; for example, airlines try to minimize human contact by encouraging passengers to do self-check-in via their mobile phone. In addition, airlines have implemented infection preventive measures in their lounges by strictly complying with the IATA's guidelines. Apart from IATA's guidelines, each country's government has also implemented regulations and restrictions regarding air transportation. During the pandemic, most of the states decided to shut down the airports, so most airlines needed to stop their operation and suspend their flight services. This situation also impacts fleet utilization. Many aircrafts that used to operate daily flights are now grounded (Suau-Sanchez et. al., 2020). This also impacts airlines' slots - the permission granted to scheduled airlines for take-off and landing at a specific time. The airlines must utilize at least $80 \%$ of their allocated slot to maintain their rights to operate the slot. Fortunately, this rule has been eased for the COVID-19 period (IATA, 2020c), yet the resolution still depends on the pandemic situation (Haanappel, 2020).

\subsection{Airline market impacts}

The COVID-19 pandemic has had a significant impact on the airline market environment. The impact mostly emerged from the limitations and restrictions imposed on air transportation during the pandemic. 
Airlines worldwide need to reduce their number of flights dramatically, especially international flights, due to the immediate airport shut down and travel restrictions. The number of daily international flights has dropped from over 20,000 flights per day in March 2020 to under 2,000 flights per day at the beginning of April 2020 (ICAO, 2020). Despite the restriction on passenger flights, air cargo flights can still operate to many destinations. Unfortunately, air cargo service demand might also drop dramatically due to a massive decrease in international trade volume (WTO, 2020). The supply for air cargo has reduced even more extensively than the air cargo's demand. This results from the suspension of passenger flights because around $30 \%$ of cargo is carried on passenger aircrafts (Boeing, 2018). Recently, there have been some signs of recovery. Some countries have allowed domestic flight operations to resume however, it might take more time before passengers will come back to air travel again due to their fear of getting infected (Lamb et. al., 2020; Wen et. al., 2020). Business passengers might be the first group of passengers that return to fly because their business requires them to travel by air (Bud \& Ison, 2017).

However, the very much improved telecommunication technology shall reduce their need for travel. It will be much harder for the leisure passenger to come back to fly. Leisure passengers are more sensitive than business passengers, and the pandemic will have a greater effect on them. Their primary journey purposes are travelling and visiting friends or family, which might be considered unnecessary or avoided during the virus (Wen et. al., 2020). According to Statista (2020), more than $30 \%$ of people in the U.K., USA, and Germany have lost their income during the COVID-19 pandemic. Losing income might also delay them from coming back to travel again due to budgetary restrictions. The market for international flights will take a longer time to recover compared to domestic flights. In addition, State quarantine requirements also makes it harder for passengers to travel. According to IATA's (2020d) survey, $80 \%$ of airline passengers are worried about State quarantine. If the passengers arrive at the destination and are subject to quarantine for a certain period, they will need to rearrange their travel plans. The COVID-19 pandemic has also had an impact on ticket prices. It is expected that ticket prices will increase due to the increase in operational costs (Suau-Sanchez et. al., 2020). However, we might observe unusual promotional prices due to the need for cash; airlines might offer a discount in order to stimulate income (Vinod, 2020).

The routes and schedules are the main product of an airline (Wittmer et. al., 2011). The impact of COVID19 on airline routes is also substantial. Most of the airlines have implemented a hub-and-spoke route network to provide more origin-destination routes to their passengers (Doganis, 2019). COVID-19 has disturbed this network, so the airlines cannot operate at some airports. As a result, it is impossible to provide some of the flight connections that were previously available before COVID-19. Therefore, the airlines cannot offer the same variety of routes.

\subsection{Airline financial impacts}

Flight suspension and a sharp drop in revenue significantly impacts airline financial performance. IATA (2020d) forecasted industry passenger revenue losses at between 63 billion to 113 billion USD. This forecast might be too optimistic since ICAO (2020) reported a loss of over 120 billion USD from January 2020 to May 2020. With all of the restrictions imposed on air transportation, airlines cannot generate revenue at a sustainable level. Revenue from air cargo flights will also decrease. WTO (2020) has forecasted that the international trade volume will drop by $13 \%$ to $32 \%$ compared to the amount in 2019 , so airlines can expect decreasing air cargo service revenue. The onboard physical distancing measure worsens the damage because the airlines cannot generate revenue by utilizing the cabin's full capacity. IATA (2020e) states that airlines can utilize only $60 \%$ of cabin capacity if they strictly comply with physical distancing measures. In addition, some passengers have pre-booked flights before the pandemic, and those flights have been suspended or cancelled. Therefore, the airlines should refund these tickets or provide the service when travel resumes 
(Monmousseau et. al., 2020). This portion of sold tickets will not generate further revenue for airlines. Decreasing revenue is not the only factor that damages the airline's financial performance.

The increasing costs of operation amplifies the damage to airlines. The infection preventive measures that airlines need to implement are costly (Budd et. al., 2020). The airlines need to provide their staff with protection equipment, which is not usually reusable. The disinfection processes for both the ground service area and inflight service areas will increase airlines' operational costs. The decrease in jet fuel's price (IATA, 2020f) might be able to absorb some damage. Unfortunately, this is still unable to compensate for the decrease in revenue and increase in costs. The debt ratio of airlines is relatively high, even before the pandemic (Aydin et. al., 2020). IATA (2020g) forecasted global airline debt to increase by $28 \%$ or 67 billion USD by the end of 2020. The airlines are striving for money to continue operating their businesses. The debt is composed of deferred tax, government loans, and financial institution loans. High levels of debt is a massive challenge for airlines under this situation that their ability to repay their debt is diminishing. For example, Thai Airways is in the process of business rehabilitation (Poonsuwan, 2020), while Avianca has now filed for bankruptcy (Rochabrun et. al., 2020). The COVID-19 pandemic has brought substantial financial difficulty to airlines. As a consequence, the global airlines' stock price has decreased dramatically. Maneenop and Kotcharin (2020) found that the U.S. and European airlines' stock price has reduced much greater than the stock price of Asian airlines.

\section{Discussion}

COVID-19 has had a tremendous impact on the airline business. Unfortunately, the airlines were not well prepared for this situation even though similar events have occurred before, e.g., Bird-flu, SARS (Brown \& Kline, 2020). Given the severity and complexity of the pandemic, many airlines have tried to respond to this crisis. When there was very limited information in the initial outbreak of the virus, airlines focused on their operational measures and followed the guidelines provided by the related organizations (Amankwah-Amoah, 2020). They focused on preventing the spread of the virus by deep cleaning the cabin and setting the new procedures for ground and in-flight services. However, some measures are not effective or efficient. For example, the physical distancing measure is almost impossible to be followed during flights (Hester, 2020; Pongpirul et. al., 2020). Furthermore, the pandemic has caused serious financial difficulty for airlines.

Many airlines have asked for government support. Rappeport and Chokshi (2020) reported that the U.S. airline industry should get 25 billion U.S. dollars support from the government. The airlines need to generate revenue from unusual channels. Some airlines have converted their passenger aircrafts to freighter aircrafts in order to offer more air cargo service (Horton, 2020). Thai Airways (2020) now offers the "Flight Experience" service that the customers can get in the flight simulators that the airline uses for pilot training. The customers can control the simulator under instructor supervision. The airlines also try to manage their costs and investments. Many airlines have reduced their fleet, delayed aircraft orders or delivery to cut off their expense. Provided that most of the flights have been suspended, the airlines need to reduce their excessive workforce since it is a significant component of airline costs (Kumaran et. al., 2019). It is expected the airlines may reduce their workforce by up to 30\% (Budd et. al., 2020; Sobieralski, 2020). The pandemic situation is still ongoing, and there are many uncertainties. It will take time before the industry recovers. Longer-term strategies are required to ensure that airlines can recover once the pandemic is under control.

\section{Conclusion}

This article contributes to the literature by examining and summarizing the impacts of COVID-19 on airlines from 3perspectives. During the pandemic, airlines have faced, and continue to face, many difficulties, and a long-term strategy is required to ensure their survival. From an operational perspective, the airlines 
need to focus on infection prevention; they need to update their procedures according to the guidelines provided by health care organizations, aviation associations and state governments. In addition, airlines need to adjust their routes and network management since some airports are still unavailable. From the perspective of the aviation market, passenger and cargo demand has greatly reduced. There are some signs of demand recovering; however, it will take up to 3 years until the situation will be fully resolved. As a result, revenue has also dramatically decreased. The financial situation of airlines continues to worsen, particularly due to high debt burden. Thus, many airlines are striving for financial support from the government.

This study has some limitations. Firstly, this study was conducted while the pandemic was still ongoing, so the data and information used in this study is not exhaustive. Secondly, the number of academic studies regarding airline business and COVID-19 was very limited. Future research should focus on the strategy and practical measures for the airlines during the crisis. It is also important to conduct the studies once the pandemic has passed, and all the impacts on the industry are known. Empirical quantitative and qualitative studies should be conducted to investigate the impact of COVID-19 on airlines systematically and to examine the strategic responses of different airlines. Future research can compare the impact of the pandemic on airline businesses from different regions or airline with different business models, e.g., full-service and lowcost airlines.

\section{Acknowledgments}

The authors appreciate Mae Fah Luang University for providing the resources needed to conduct this study.

\section{References}

Amankwah-Amoah, J. (2020). Note: Mayday, Mayday, Mayday! Responding to environmental shocks: Insights on global airlines' responses to COVID-19. Transportation Research Part E: Logistics and Transportation Review, 143, 102098.

Aydın, U., Karadayi, M. A., \& Ülengin, F. (2020). How efficient airways act as role models and in what dimensions? A superefficiency DEA model enhanced by social network analysis. Journal of Air Transport Management, 82, 101725.

Belobaba, P., Odoni, A., \& Barnhart, C. (Eds.). (2015). The global airline industry. John Wiley \& Sons.

Boeing. (2018). World air cargo forecast 2018-2037. Boeing, Illinois, United States.

Bowen Jr, J. T., \& Laroe, C. (2006). Airline networks and the international diffusion of severe acute respiratory syndrome (SARS). Geographical Journal, 172(2), 130-144.

Brown, R. S., \& Kline, W. A. (2020). Exogenous shocks and managerial preparedness: A study of US airlines' environmental scanning before the onset of the COVID-19 pandemic. Journal of Air Transport Management, 89, 101899.

Budd, L., \& Ison, S. (Eds.). (2020). Air transport management: an international perspective. Routledge.

Budd, L., Ison, S., \& Adrienne, N. (2020). European airline response to the COVID-19 pandemic-Contraction, consolidation and future considerations for airline business and management. Research in Transportation Business \& Management, 37, 100578.

Collins, J. A., \& Fauser, B. C. (2005). Balancing the strengths of systematic and narrative reviews.

Doganis, R. (2009). Flying off course IV: airline economics and marketing. Routledge.

Evler, J., Asadi, E., Preis, H., \& Fricke, H. (2021). Airline ground operations: Optimal schedule recovery with uncertain arrival times. Journal of Air Transport Management, 92, 102021.

Gudmundsson, S. V., Cattaneo, M., \& Redondi, R. (2021). Forecasting temporal world recovery in air transport markets in the presence of large economic shocks: The case of COVID-19. Journal of Air Transport Management, 91, 102007. Haanappel, P. P. (2020). Slots: Use It or Lose It. Air and Space Law, 45(Special issue).

Hertzberg, V. S., Weiss, H., Elon, L., Si, W., Norris, S. L., \& FlyHealthy Research Team. (2018). Behaviors, movements, and transmission of droplet-mediated respiratory diseases during transcontinental airline flights. Proceedings of the National Academy of Sciences, 115(14), 3623-3627. 
Hester, E. (2020). Coronavirus means social distancing. For flight attendants, it's suddenly easier.

Horton, W. (2020). 7 Unusual ways aircraft now fly cargo during coronavirus outbreak.

International Air Transport Association. (2006). Economic briefing: Avian flu. IATA, Montreal, Canada.

International Air Transport Association. (2019). World air transport statistic. IATA, Montreal, Canada.

International Air Transport Association. (2020a). Recovery delayed as international travel remains locked down.

International Air Transport Association. (2020b). Guidance for cabin operations during and post pandemic.

International Air Transport Association. (2020c). World wide airports slot.

International Air Transport Association. (2020d). IATA proposes alternatives to quarantine.

International Air Transport Association. IATA calls for passenger face covering and crew masks [cited 2020 Jul 8].

International Air Transport Association. (2020f). Jet fuel price monitor.

International Air Transport Association. (2020g). Airline debt to balloon by $28 \%$ - Heavy new debt levels will weigh down recovery.

International Civil Aviation Organization. (2020a). Global COVID-19 airport status.

International Civil Aviation Organization. (2020b). Effect of novel corona virus on civil aviation. [PowerPoint Slides].

International Civil Aviation Organization. (2021). 2020 passenger totals drop 60 percent as COVID-19 assault on international mobility continues.

Kumaran, V. V., Kheng, K., Al Shdaifat, F. H., Gorondutse, A. H., \& Abdullah, S. S. (2019). Does labour costs matter for the airline industry?. Academy of Strategic Management Journal, 18(2), 1-8.

Kuo, H. I., Chen, C. C., Tseng, W. C., Ju, L. F., \& Huang, B. W. (2008). Assessing impacts of SARS and Avian Flu on international tourism demand to Asia. Tourism Management, 29(5), 917-928.

Lamb, T. L., Winter, S. R., Rice, S., Ruskin, K. J., \& Vaughn, A. (2020). Factors that predict passengers willingness to fly during and after the COVID-19 pandemic. Journal of air transport management, 89, 101897.

Machida, M., Nakamura, I., Saito, R., Nakaya, T., Hanibuchi, T., Takamiya, T., ... \& Inoue, S. (2020). Adoption of personal protective measures by ordinary citizens during the COVID-19 outbreak in Japan. International Journal of Infectious Diseases, 94, 139-144.

Macilree, J., \& Duval, D. T. (2020). Aeropolitics in a post-COVID-19 world. Journal of Air Transport Management, $88,101864$.

Maneenop, S., \& Kotcharin, S. (2020). The impacts of COVID-19 on the global airline industry: An event study approach. Journal of air transport management, 89, 101920.

Mangili, A., \& Gendreau, M. A. (2005). Transmission of infectious diseases during commercial air travel. The Lancet, 365(9463), 989-996.

Mason, K. J. (2005). Observations of fundamental changes in the demand for aviation services. Journal of Air Transport Management, 11(1), 19-25.

Monmousseau, P., Marzuoli, A., Feron, E., \& Delahaye, D. (2020). Impact of Covid-19 on passengers and airlines from passenger measurements: Managing customer satisfaction while putting the US Air Transportation System to sleep. Transportation Research Interdisciplinary Perspectives, 7, 100179.

Morrison, J., Bonnefoy, P., Hansman, R. J., \& Sgouridis, S. (2010, September). Investigation of the impacts of effective fuel cost increase on the us air transportation network and fleet. In 10th AIAA Aviation Technology, Integration, and Operations (ATIO) Conference (p. 9202).

Pine, R., \& McKercher, B. (2004). The impact of SARS on Hong Kong's tourism industry. International Journal of Contemporary Hospitality Management.

Pongpirul, K., Kaewpoungngam, K., Chotirosniramit, K., \& Theprugsa, S. (2020). Commercial airline protocol during COVID-19 pandemic: An experience of Thai Airways International. Plos one, 15(8), e0237299.

Poonsuwan, W. (2020). Business rehabilitation: Thai Airways to lead COVID-19 induced debt restructuring.

Rappeport, A., \& Chokshi, N. (2020). Crippled Airline Industry to Get \$25 Billion Bailout, Part of It as Loans. The New York Times.

Rochabrun, M.C., Kumar, K., \& Bocanegra, N.S. (2020). World's second-oldest airline, Avianca, driven to bankruptcy by coronavirus.

Sobieralski, J. B. (2020). COVID-19 and airline employment: Insights from historical uncertainty shocks to the industry. Transportation Research Interdisciplinary Perspectives, 5, 100123. 
Suau-Sanchez, P., Voltes-Dorta, A., \& Cugueró-Escofet, N. (2020). An early assessment of the impact of COVID-19 on air transport: Just another crisis or the end of aviation as we know it?. Journal of Transport Geography.

Statista. (2020). Share of people who lost income due to the COVID-19 / coronavirus pandemic in the United States, United Kingdom and Germany 2020.

Thai Airways. (2020). Thai simulator experience.

The World Bank. (2021). Air transport, passengers carried.

United Nations Industrial Development Organization. (2020). Coronavirus: the economic impact.

Vinod, B. (2020). The COVID-19 pandemic and airline cash flow. Journal of Revenue and Pricing Management, 19(4), 228-229.

Wen, J., Kozak, M., Yang, S., \& Liu, F. (2020). COVID-19: potential effects on Chinese citizens' lifestyle and travel. Tourism Review.

Wittmer, A., Bieger, T., \& Müller, R. (Eds.). (2011). Aviation systems: management of the integrated aviation value chain. Springer Science \& Business Media.

World Health Organization. (2020a). WHO timeline - COVID-19.

World Health Organization. (2020). Modes of transmission of virus causing COVID-19: implications for IPC precaution recommendations: scientific brief, $27 \quad$ March $2020 \quad$ (No. nCoV/Sci_Brief/Transmission_modes/2020.1). World Health Organization.

World Trade Organization (WTO). (2020). Trade set to plunge as COVID-19 pandemic upends global economy.

Zhu, Z., Lian, X., Su, X., Wu, W., Marraro, G. A., \& Zeng, Y. (2020). From SARS and MERS to COVID-19: a brief summary and comparison of severe acute respiratory infections caused by three highly pathogenic human coronaviruses. Respiratory research, 21(1), 1-14. 